\title{
PARADIGMA PENDIDIKAN SENI MELALUI IDEOLOGI LIBERAL DAN IDEOLOGI KONSERVATIF DALAM MENGHADAPI ERA REVOLUSI INDUSTRI 4.0
}

\section{THE ART EDUCATION PARADIGM THROUGH LIBERAL IDEOLOGY AND CONSERVATIVE IDEOLOGY IN FACE OF INDUSTRIAL REVOLUTION ERA 4.0}

\author{
Richard Junior Kapoyos ${ }^{1}$ \\ ${ }^{1}$ Sekolah Tinggi Theologia Abdiel, Ungaran, Indonesia \\ ${ }^{(*)} \bowtie$ (e-mail) richardkapoyos@stt-abdiel.ac.id ${ }^{1}$
}

\begin{abstract}
Abstrak
Landasan paradigma pendidikan adalah unsur dari kebudayaan bangsa. Melalui ideologi liberal pendidikan seni dan ideologi konservatif akan memberi ruang pada individu untuk mengembangkan kepercayaan diri dengan kebebasan yang dimiliki. Pendekatan pendidikan dalam seni melalui paham konservativisme lebih kepada perlunya melestarikan dan meneruskan keyakinan dan praktik seni yang sudah mapan. Pada hakekatnya pendidikan seni memiliki subtansi sebagai pendidikan kreatif dan pendidikan estetika yang berfungsi sebagai media dalam upaya pengembangan kreativitas budaya. Sehingga dengan sendirinya subtansi pendidikan seni secara langsung sebagai perwujudan nilai karakter subjek didik. Dengan metode pembelajaran melalui pendidikan seni, pendidik harus berfungsi sebagai agen pembaharuan yang berperan sebagai komunikator dan berfungsi sebagai pelayanan yang dilandasi olah rasa, profesional dan selalu memiliki kesadaran akan tanggung jawab serta berfungsi sebagai narasumber yang terpercaya.
\end{abstract}

Kata kunci: Pendidikan Seni, Revolusi Industri 4.0, Ideologi Liberal, Ideologi Konservatif

\begin{abstract}
The foundation of the education paradigm is an element of the nation's culture. Through the liberal ideology of art education and conservative ideology will provide space for individuals to develop confidence with the freedom they have. The educational approach in art through the understanding of conservativism is more the need to preserve and continue the established beliefs and practices of art. In essence, art education has the substance of creative education and aesthetic education that functions as a medium in the effort to develop cultural creativity. So that by itself the substance of art education is directly as a manifestation of the students' character's character values. With the method of learning through art education, educators must function as renewal agents who act as communicators and function as services that are based on feeling, professional and always have an awareness of responsibility and function as trusted informants.
\end{abstract}

Keywords: Arts Education, Industrial Revolution 4.0, Liberal Ideology, Conservative Ideology.

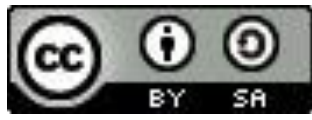

Diterima: 20 Mei $2020 \quad$ Revisi: 18 Juni $2020 \quad$ Terbit Online: 20 Juni 2020 


\section{Pendahuluan}

Isu global yang makin ramai diperbincangkan dalam forum-forum ilmiah dan media massa saat ini adalah perihal era baru yang disebut dengan era revolusi industri 4.0. Era ini merupakan sebuah masa yang menempatkan manusia pada posisi "dimanjakan". Mengapa demikian? Dengan berkembangnya teknologi informasi saat ini, hampir semua aspek kehidupan manusia memberikan dampak pada aktivitas manusia yang semakin mudah dan fleksibel. Kondisi inilah yang seolah-olah memanjakan manusia dengan segala kebutuhan dan keperluannya. Era revolusi industri generasi keempat hadir dengan memberikan berbagai tantangan khususnya bagi dunia pendidikan. Perubahan secara sporadis dan disruptif ini tentu harus disikapi dengan menyesuaikan diri terhadap perubahan tersebut. Pendidikan sebagai aspek penting bagi kehidupan manusia harus mampu menciptakan dan mempersiapkan generasi muda yang siap bersaing di era revolusi industri 4.0 saat ini. Keterampilanketerampilan yang beberapa puluh tahun lalu dibutuhkan mungkin tidak akan relevan lagi di era revolusi industri 4.0 saat ini. Seperti yang telah kita ketahui, kehadiran era revolusi industri 4.0 bersamaan dengan keberadaan kita yang memasuki abad ke-21. Penanda abad ke-21 dan revolusi industri generasi keempat ini adalah lahirnya kecanggihan teknologi dan informasi yang kian tak terbendung. Perubahan ini membawa sederet pengaruh dan tantangan yang harus disikapi dengan bijak bagi pelaku dunia pendidikan. Tipisnya jarak antara realitas maya dan realitas nyata semakin mengukuhkan bahwa kita harus berupaya untuk segera menyesuaikan dengan perubahan ini. Sekadar menoleh ke belakang, masih banyak lembaga pendidikan di Indonesia yang menerapkan sistem tradisional dalam aktivitasnya.

Hal ini perlu menjadi perhatian serius bagi pemerintah dan kalangan akademisi untuk membenahi sistem pendidikan tersebut. Kita tentu tidak ingin mendengar lagi bahwa pendidikan kita masih mengadopsi sistem "jadul" sehingga menjadi sesuatu yang kontraproduktif dengan laju perubahan zaman dan perkembangan teknologi. Intinya, pendidik dan lembaga pendidikan harus beradaptasi dengan dunia baru tersebut agar pendidikan dapat berselancar di atas gelombang pergeseran dan bukan malah tenggelam di bawahnya (Sumardianta \& AW, 2018). Selama bertahun-tahun, beberapa keterampilan yang diprioritaskan dalam program pendidikan di sekolah-sekolah umum adalah membaca, menulis, dan berhitung atau matematika. Di samping itu, saat ini sekolah-sekolah menawarkan kepada peserta didik seperti pembelajaran bahasa asing, seni, geografi, ilmu pengetahuan alam, dan studi sosial. Namun faktanya, semua itu belumlah dipandang cukup karena fokus utama saat ini adalah karir dan kesiapan perguruan tinggi (Freeman, 2016).

Pendidikan merupakan proses pengendalian diri yang senantiasa dapat meningkatkan suatu pemahaman terhadap kebudayaan sebagai seorang warga negara yang sadar terhadap budaya yang dimiliki. Kepribadian, kecerdasan, keterampil, memelihara hubungan yang baik antara sesama manusia dan lingkungannya, dan mampu mengembangkan daya estetika adalah tujuan pendidikan nasional. Tujuan menurut definisi tersebut adalah pengembangan daya perubahan yang diinginkan pada bidang asasi secara individual. Hal ini, merujuk kepada kebebasan individual dalam proses pendidikan sehingga individu dapat mengembangkan pola pikir dan keperibadiannya sebagai usaha sadar dan terencana dalam proses pembelajaran. (Jalaluddin, 2011:142). Mencerdaskan kehidupan bangsa merupakan tujuan dari pendidikan nasional sebagaimana tertaut dalam Undang-Undang Republik Indonesia No 20 tahun 2003 tentang Sistem Pendidikan Nasional (dalam Triyanto, 2017: lihat juga: Tilaar, 2012). Sebagai bangsa dengan tujuan pembentukan insani yang cerdas, pokok utama dapat dicermati dari 
landasan pendidikan yang dirunut. Landasan pendidikan merupakan sebuah paradigma yang sejalan dengan pranata sosial sejak zaman dulu sampai saat ini. Dengan perkembangan teknologi dan informasi pada awal abad XXI seorang warga negara perlu untuk menumbuhkembangkan aspek kreatif, apresiasi, dan ekspresi melalui jalur pendidikan. Hal ini, tentunya dibangun dari sebuah pandangan ideologis dengan kata lain sebuah paradigma dasar yang dijadikan sebagai acuan, pandangan, atau landasan dalam menyikapi praktek pendidikan saat ini.

Pendidikan saat ini dilegitimasi sebagai upaya memberikan jawaban untuk melanggengkan sistem pranata sosial pada setiap perubahan sosial yang terjadi. Namun, dalam memberikan jawaban yang logis, hanya bisa dijawab melalui suatu paradigma atau ideologi pendidikan yang mendasarinya. Dalam hal ini seni melalui pendidikan, paradigma pendidikan melalui seni meletakkan dua paham ideologis yang saling terintegrasi yaitu ideologi konservatif dan ideologi liberal (lihat: O'Neill dalam Fakih, 2002; lihat juga : Triyanto 2017). Latar belakang bangsa yang multibudaya merupakan landasan yang terbangun sejak zaman dulu. Praktek pendidikan nasional yang berawal dari budaya daerah yang beranekaragam suku, bahasa, dan kesenian dijadikan sebagai kaca mata dalam praktek pendidikan. Dalam hal ini, ideologi konservatif merujuk kepada filsafat pendidikan multikultural dan ideologi liberal merujuk kepada filsafat pendidikan humanisme dan filsafat pendidikan progresivisme sebagai tawaran dalam tulisan ini sebagai landasan dalam paradigma pendidikan saat ini sehingga dua ideologi ini dapat dijadikan sebagai substansi dalam dunia pendidikan nasional (lihat; Triyanto, 2017).

Landasan paradigma pendidikan seni dari sudut pandang kebudayaan, akan di lihat melalui pendekatan kesenian nusantara dengan fokus kepada pembentukan karakter individu sebagai subjek didik yang kreatif, apresiatif, dan ekspresif. Dalam membentuk ulang (merevolusi) karakter bangsa sebagai persoalan yang umum di perbincangkan di era kontemporer dengan kecanggihan teknologi dan informasi seperti sekarang ini, tidak khayal jika seni sebagai objek dan merupakan salah satu unsur dari kebudayaan dengan nilai dan norma yang melingkupinya sehingga dapat diterapkan di dalam dan melalui pendidikan seni dalam rangka mencapai tujuan pendidikan nasional (lihat: majalah Jendela edisi VIII, Desember 2016) Upaya dalam menegaskan landasan pendidikan sebagai pembentukan jati diri, yang cerdas, berkarakter, inovatif, kreatif, dan memiliki daya apresiatif yang tinggi tepat jika pendidikan berbasis ke-seni-an dijadikan sebagai sebuah pendekatan dan/atau sebagai media dalam satuan pendidikan, dalam arti yang luas pendidikan melalui seni atau pemfungsian seni dengan mengutip istilah Herbert Read education trought art dan pendidikan dalam seni atau konsep penularan seni dalam istilah Eisner education in art (dalam Rohidi; 2014, Triyanto; 2017, Soehardjo, 2012).

Mengingat pandangan masyarakat umum yang beranggapan, untuk apa seni diajarkan? bagaimana peranan seni dalam dunia pendidikan? dan mempelajari seni baik itu rupa, musik, tari, dan teater atau dalam kurikulum pendidikan dinamakan seni budaya hanya berupa proses dimana individu atau subjek didik belajar untuk terampil dalam mengembangkan kerampilan menggambar, bernyanyi, bermusik, dan berteater. Anggapan masyarakat semacam ini tidak sejalan dengan praktek pembelajaran seni secara khusus. Oleh sebab itu, pendidikan yang berbasis budaya dengan unsur kesenian yang melengkapinya sebagai tolak ukur landasan pendidikan. Dengan demikian, penulis menawarkan sumbangan pikiran yang dapat menjawab pertanyaan mengenai bagaimana sudut pandang paradigma pendidikan seni melalui ideologi liberal dan ideologi konservatif? bagaimana paradigma pendidikan seni 
dalam penerapan metode pembelajaran? dan bagaimana peran pendidikan Seni sebagai penguatan karakter sehingga masyarakat umum terkhusus kepada pendidik (guru seni budaya) melalui paradigma yang ditawarkan dapat menjadi spirit ideologis pendidikan dalam dunia pendidikan saat ini.

\section{Pembahasan}

\section{Revolusi Industri 4.0}

Sesuai dengan namanya, era revolusi industri 4.0 merupakan fase lanjutan dari revolusi industri sebelumnya. Profesor Schwab, seorang ekonom Jerman memperkenalkan istilah ini pada tahun 2017 melalui bukunya berjudul The Fouth Industrial Revolution. menurutnya, era revolusi industri generasi keempat ini ditandai dengan perkembangan teknologi digital yang seolah-olah telah menyamarkan atau mengaburkan antara dimensi fisik, digital, dan biologis. Artinya, dalam kehidupan manusia saat ini seolah-olah tidak ada lagi sekat-sekat yang membatasi antar-dimensi tersebut. Hadirnya revolusi industri 4.0 mengubah pola dan tatanan kehidupan masyarakat dunia secara fundamental. Era ini familiar juga disebut sebagai era disrupsi, sebuah era yang menghadirkan fenomena-fenomena yang tidak pernah kita bayangkan sebelumnya. Aspek-aspek kehidupan manusia semakin disamarkan dari sekatsekat yang membatasinya. Hanya dengan gerakan jemari di gadget, seseorang dapat melakukan aktivitas seperti berbelanja, melakukan transaksi pembayaran, transfer, booking pesawat dan hotel, yang dulu harus dilakukan dengan mendatangi kantor atau pusat perbelanjaan Merujuk pada sejarah perubahan industri dunia, telah terjadi perubahan secara mendasar semenjak abad ke-18. Perubahan pertama dalam dunia indutri itu disebut dengan istilah era revolusi industri 1.0. Revolusi ini merupakan perubahan pertama dalam bidang industri yang ditandai dengan beralihnya bidang pekerjaan dari pertanian dan perkebunan menjadi industri berbasis pabrik. Era ini identik dengan penemuan mesin uap yang benarbenar mengubah tatanan kehidupan masyarakat pada saat itu. Tenaga-tenaga manusia dan hewan sudah mulai digantikan dengan beberapa tenaga mesin. Artinya, terjadi efisiensi yang cukup besar sehingga menghasilkan keuntungan yang berlipat. Namun tidak dapat dimungkiri pula, terjadi pengurangan tenaga kerja karena sebagian pekerjaan tersebut telah diambil alih oleh peranan mesin.

Pada abad ke-19, mulai terjadi kembali perubahan besar yang disebut dengan era revolusi industri 2.0. Sebuah era yang benar-benar mulai mewujudkan halhal yang selama ini hanya menjadi impian manusia. The second revolution ini ditandai dengan berbagai penemuan teknologi yang didasari oleh energi listrik, penemuan pesawat telepon, hingga pesawat atau kapal terbang. Hal yang paling menonjol dalam era ini adalah mulainya pabrikpabrik yang didasarkan pada produksi massal. Artinya, sistem produksi telah diatur untuk menghasilkan produk/barang dengan jumlah yang lebih banyak yang tidak dapat dikerjakan oleh tenaga manusia. Pada abad ke-20, terjadi kembali perubahan besar dalam dunia industri dan disebut sebagai revolusi industri 3.0. Pada era ini, dunia industri diwarnai dengan penggunaan elektronik dan teknologi informasi dengan tujuan untuk efisiensi dan jumlah produksi. Artinya, bagaimana pabrik-pabrik dapat memproduksi barang dan jasa dalam jumlah yang besar namun dengan efisiensi waktu dan tenaga. Untuk itulah, digunakan pemrograman yang didasarkan pada teknologi dalam proses produksinya.

Terjadinya perubahan dalam dunia industri ini bukannya tanpa meninggalkan dampak. Ada berbagai konsekuensi yang harus terima oleh masyarakat dunia. Pergeseran pada era ini tidak hanya berlaku pada praktik produksi, distribusi, dan konsumsi makanan dan pelayanan 
tetapi juga merambah ke perubahan yang fundamental seperti pada cara hidup manusia secara individu dan strata sosial (Janíková \& Kowaliková, 2017). Pergeseran ini dimulai pada dekade kedua abad ke-21 ini yang ditandai dengan transformasi berbagai bidang, termasuk gaya hidup, pekerjaan, cara berpikir, dan lain-lain. Saat ini, teknologi digital berdampak sistemik dan masif di seluruh aspek kehidupan manusia, baik bidang ekonomi, sosial, politik, dan bahkan pendidikan. Pada bidang ekonomi, kita dapat merasakan perubahannya semenjak makin menjamurnya e-commerce atau perdagangan elektronik yang hadir seperti bukalapak, traveloka, lazada, elevania, dan lain-lain. Munculnya berbagai startup ini memberikan kemudahan bagi masyarakat dalam berbelanja kebutuhannya tanpa harus datang ke department store atau toko. Di samping itu, industri transportasi juga mengalami perubahan yang drastis dan dapat dikatakan mengalami disrupsi. Kemapanan moda transportasi lama yang didominasi oleh ojek dan angkutan tradisional kini telah tergeser oleh kehadiran mode transportasi berbasis daring (dalam jaringan) atau online. Gojek, grab, dan uber merupakan beberapa moda transportasi yang kini mengusai di seluruh dunia walaupun pada awal kemunculannya banyak mendapat tentangan dari para pebisnis transportasi tradisional. Revolusi industri 4.0 juga berpengaruh cukup signifikan dalam bidang pendidikan.

Reorientasi pendidikan dari pola teacher centered learning menuju student centered learning mau tidak mau memang harus mengikutsertakan aplikasi teknologi yang merupakan produk revolusi industri 4.0 dalam proses pendidikan. Artinya, pendidikan tidak dapat dilepaskan dari pengaruh era ini karena salah satu fungsi pendidikan adalah menghasilkan lulusan yang memiliki kompetensi yang dibutuhkan oleh tuntutan era tersebut. Terlepas dari beberapa kritikan para ahli terkait ketidaksetujuannya dalam memahami pendidikan seperti layaknya sebuah pabrik, namun kondisi ini memang tidak dapat dielakkan lagi. Pooworawan menyebutkan bahwa institusi pendidikan diibaratkan sebagai era produksi massal yang menempatkan mahasiswa sebagai produknya, kurikulum sebagai spesifikasi produk, proses ujian sebagai proses quality control, ijazah sebagai kartu garansi, dan institusi pendidikan sebagai brand atau merk produk (Puncreobutr, 2016).

Bila kita cermati, semakin banyak bermunculan platform yang bergerak di bidang pendidikan yang menggunakan aplikasi teknologi informasi saat ini. Berbagai jenis platform pendidikan seperti bimbingan belajar, kursus dan lain-lain kian menyemarakkan dunia pendidikan di era revolusi industri 4.0 ini. Salah satunya yang kini menarik ribuan pengguna adalah Ruangguru. Startup ini makin dilirik oleh generasi milenial di Indonesia terlebih lagi setelah Iqbaal Ramadhan ditunjuk sebagai Brand Ambassador-nya. Startup ini merupakan layanan bimbingan belajar secara online yang dapat diakses dengan menggunakan gadget atau smartphone. Artinya, bimbingan belajar tidak lagi dimaknai sebagai proses bimbingan yang berupa sistem face to face antara tutor dan peserta didiknya. Dengan era yang berbeda, tentu saja kompetensi dan keterampilan yang dibutuhkan oleh dunia kerja akan berbeda pula. Menurut World Economic Forum (2015), ada 16 keterampilan yang harus dikuasai oleh peserta didik yang dikelompokkan menjadi 3 bagian, yaitu foundational literacies, competencies, dan character qualities. Artikel ini mengulas beberapa kompetensi inti yang sangat diharapkan dikuasai oleh mahasiswa dalam menyongsong era revolusi industri 4.0. Berbagai kompetensi tersebut adalah keterampilan berpikir kritis atau problemsolving, kreativitas, berkomunikasi, dan kolaborasi. Lebih lanjut, artikel ini juga menyoroti berbagai pendekatan pembelajaran bahasa di perguruan tinggi dalam mengembangkan keempat keterampilan tersebut.

\section{Paradigma Pendidikan Seni Melalui Ideologi Liberal dan Ideologi Konservatif}


Pemahaman klasik bahwa pendidikan seni pada awalnya mengandung pengertian usaha sadar untuk menularkan seni sebagai wujud dari transformasi budaya dari generasi ke generasi yang dilakukan oleh para seniman ternama (master/empu) sebagai pihak penular kepada personal atau individu yang siap menjadi seniman yang handal. Seiring dengan perkembangannya, dimana pendidikan seni berpindah dari sosok penular ke tangan pakar seni yang berdampak terhadap proses pendidikan. Maka pengertian pendidikan seni bukan lagi sebagai konsep yang tunggal. Secara hakiki, sebagai konsep yang baru pendidikan seni adalah usaha sadar untuk menyiapkan peserta didik melalui kegiatan bimbingan, pengajaran dan/atau latihan agar menguasai kemampuan berkesenian sesuai dengan peran yang harus dimainkannya peran di sini adalah memfungsidikkan seni. Artinya bukannya kemampuan memahami hal yang terkait dengan kegiatan seni dan kemampuan menghasilkan karya seni, akan tetapi satuan kemampuan yang disebut hasil pengajaran yang berupa kemampuan berkesenian dan hasil ikutan yang berupa kemampuan non berkesenian yang kontekstual berupa sikap dan nilai seperti kemampuan percaya diri, kemampuan menghargai pendapat orang lain, dan bertanggung jawab. Hasil ikutan ini ditempatkan sebagai hasil belajar yang utama, sedang hasil pengajaran sebagai sarananya. (Soehardjo, 2012:13-15).

Tradisi liberal dalam sistem pendidikan akan memberikan ruang pada individu untuk mengembangkan kepercayaan diri dan kekebasannya. Paham liberal ini memiliki dasar pikiran bahwa nilai kebebasan sebagai dasar kemampuan rasional dalam menentukan pola-pola kehidupan manusia yang mandiri. Jadi, fokus dan tujuan kembali kepada individu. Spirit humanisme dalam pendidikan seni tak lepas dari menuntun subjek didik menjadi sesosok yang dapat menghargai diri sendiri dan menghargai pendapat orang lain melalui berkegiatan seni dalam upaya mengembangkan kreativitas dan ekspresinya sehingga terbentuk pribadi yang kritis, kreatif, dan memiliki kesadaran dalam menghargai nilai-nilai budaya sebagai anggota masyarakat. Dan, oleh sebab itu tradisi liberal dalam paham humanisme ketika dirujuk dalam pendidikan seni secara langsung telah bersifat humanisik, karena spirit ideologi humanisme pendidikan telah terimplementasi di dalamnya. Paham humanisme bahwa peserta didik di sini dipandang sebagai subjek sehingga dapat menjadi pelaku utama dalam memaknai nilai-nilai yang dihadapinya. Pendidikan seni secara subtansial memiliki visi dan misi dalam upaya memanusiakan manusia melalui kegiatan berkesenian dengan mengembangkan daya kreativitas, apresiasi, dan ekspresi individu.

Paham progresivisme ketika ditautkan ke dalam pendidikan seni akan memberi ruang pada setiap subjek didik untuk berekspresi secara kreatif serta inovatif sebagai bekal hidup dalam menghadapi masa depannya untuk mengikuti perkembangan atau kemajuan kehidupan. Melalui pendekatan pendidikan dalam seni dalam konsep Elliot W Eisner (1972) education in art (dalam Soehadjo, 2012, liat juga: Rohidi, 2014, liat juga: Triyanto, 2017) sejalan dengan paham liberal dengan mementingkan kepada rana ekspresif estetik atau kreativitas individu sebagai tujuan pendidikan dalam seni dengan memberikan kepada subjek didik motivasi dalam menumbuhkan kreativitas. Sehingga mampu mengatasi segala masalah yang berkembang di lingkungannya.

Adapun ideologi pendidikan konservatif. Pemahaman ini cendrung memusatkan perhatiannya kepada perlunya melestarikan dan meneruskan keyakinan-keyakinan dan praktik-praktik seni yang sudah mapan sebagai cara untuk menjamin pertahanan hidup secara sosial. Kesadaran bersikap dan berperilaku, menghargai dan menerima keberagaman atau perbedaan budaya, persatuan dan kesatuan serta kesetaraan merupakan sifat yang senantiasa dimiliki oleh setiap masyarakat Indonesia secara umum. Maka dalam hal ini 
ideologis yang mendasari adanya sikap tersebut di kenal sebagai ideologi multikultural. Secara hakikat, dalam pendidikan seni dengan sendirinya telah berfungsi sebagai media pendidikan multikultural. Peran dan fungsi inilah yang menjadi wujud dalam kegiatan aprasitif estetis. Pendidikan multikultural sekaligus dapat mengembangkan karakter siswa agar mampu bersikap humanis, demokratis, dan pluralis. (lihat: Soehardjo, 2012, lihat juga: Triyanto, 2017).

Selain pendidikan dalam seni. Pendidikan seni juga diimplementasikan ke dalam sebuah instrumen pendekatan. Pendekatan yang dimaksud mengutip Herbert Read (1970) (dalam Soehadjo, 2012, liat juga: Rohidi, 2014, liat juga: Triyanto, 2017) education through art (pendidikan melalui seni). Pendekatan melalui seni teraplikasi melalui pendidikan seni di sekolah umum yang berorientasi sebagai sarana mengembangkan potensi individu untuk mempersiapkan masa depannya. Dengan kata lain education through art lebih menekankan proses dari pada hasil, sasarannya tidak menjadikan anak didik sebagai ahli dalam bidang kesenian (perupa, pemusik, penari, dan peteater) melainkan sebagai penciptaan situasi yang memunculkan pengalaman sensasi untuk berimajinasi dan berekspresi berupa kegiatan berapresiasi dan berkreasi. Maka hal ini mengandung maksud bahwa seni dijadikan sebagai sarana untuk mewujudkan tercapainya tujuan pendidikan secara umum dan bukan untuk kepentingan seni itu sendiri.

Adapun menurut Pamadhi (2012:31) juga mengutip Herbert Read (1970) dengan prinsip pendidikan yang di dasari oleh seni, dalam hal ini seni sebagai; (1) sistem nilai dalam belajar mengajar (2) sebagai metode atau cara mengajar (3) sebagai alat mendidikkan dam melatih keterampilan serta kecakapan hidup (life skill) (4) Sebagai karya yang dapat dipelajari dan digunakan untuk menyatakan gagasan ide dan melatih kemampuan berimajinasi.

Dari pemaparan tersebut, secara sederhana sudut pandang pendidikan seni melalui ideologi liberal dan konservatif sesungguhnya pendidikan seni mengarah kepada dua hal, yaitu sebagai media pendidikan ekspresif artistik (pengembangan daya cipta dan ekspresi) dan sebagai apresiatif estetis (pengembangan daya apresiasi). Dengan demikian pendidikan seni memiliki subtansi sebagai pendidikan kreatif dan pendidikan estetika yang berfungsi sebagai media dalam upaya pengembangan kreativitas budaya. Sehingga dengan sendirinya subtansi pendidikan seni secara langsung sebagai perwujudan nilai-nilai karakter subjek didik.

\section{Paradigma Pendidikan Seni dalam Pengaplikasiannya}

Sejalan dengan pandangan London dalam Centre for Art Education, Maryland Institute College of Art (2004) melalui paraktek pengajaran seni perlu untuk mempertimbangkan pendekatan holistik, yang oleh London menggolongkannya dalam pikiran (mind), tubuh (body), dan jiwa (spirit) dapat dijelaskan sebagai berikut; (1) pikiran (mind), dalam pembelajaran seni, elemen-elemen dalam pikiran secara langsung merupakan bagian dari Pendekatan holistik. Seperti rasa heran, kagum, intuisi, mimpi, fantasi, alam bawah sadar, elemen pikiran ini selalu akrab bagi setiap seniman atau seseorang yang telah memiliki pikiran yang kreatif.

Dengan demikian pendidik seni tidak harus mengajar orang bagaimana untuk bermimpi, atau membayangkan, mengembangkan intuisi, atau harus memiliki pemikiran alam bawah sadar karena bagian-bagian pikiran ini telah dimiliki oleh setiap individu (2) tubuh (body), tubuh yang sehat akan selalu mempengaruhi pikiran. Artinya, setiap organ ataupun sel-sel di dalam tubuh senantiasa mempengaruhi tingkah laku serata kecerdasan dalam melakukan tindakan berkesenian. Oleh sebab itu, para pendidik-pendidik seni pada pada umumnya harus 
mengetahui aktivitas terpenting yang bekerja di dalam tubuh sehingga tidak menghambat seseorang dalam melakukan aktivitas. Seperti fungsi otak kecil, kulit, dan sistem saraf (3) Jiwa (spirit) perlu diketahui bahwa jiwa secara langsung adalah pusat spiritual utama. Maka, setiap individu tidak perlu heran jika kelambanan dalam berfikir dipengaruhi dari tubuh yang menyebabkan keterbatasan kreativitas. Sehingga jiwa memiliki peranan yang penting dalam melakukan segala aktivitas (pembelajaran). jika hal ini diterapkan maka sebuah gagasan mengalir dengan mudah, cepat, fokus, terkonsentrasi, pemahaman lebih jelas, singkat, menarik, dan tentunya mendapatkan sebuah pengalaman estetik.

Sebagai contoh dalam melihat estetika, kita dapat mebedakan tari tradisi Melayu, Bali, dan Makassar. Dari tiga daerah ini dapat di lihat keindahan-keindahan yang berbeda, pada penari Melayu gerak tubuh merupakan bagian dari keindahan, pada penari Bali pengolahan mata merupakan suatu unsur keindahan, sedangkan pada tari Makassar ornamen fisik berupa kostum sebagai letak keindahan tariannya. Estetika yang berbeda inilah yang perlu mendapatkan perhatian serius dalam memahami makna-makna yang menjadi simbol kedaerahan yang hadir melalui tarian sebagai suatu kesatuan yang menyatu dengan pikiran.

Sejalan dengan London, dikutip dari majalah Jendela (dalam Kementrian Pendidikan dan Kebudayaan edisi IV/Agustus/2016) mengenai sembilan Tari Bali menjadi warisan budaya dunia tak benda oleh Komite Warisan Budaya Tak Benda United Nations Educational Scientific, dan Cultural Organization (UNESCO) di Windhoek, Namibia tahun 2015. Dari sembilan tari tradisional Bali tiga diantaranya tergolong sebagai tarian sakral yaitu Tari Renjang, Tari Sanghyang Dadari dan Tari Baris dapat di jadikan sebagai contoh pendekatan holistik di sini fungsi tarian dalam kehidupan masyarakat Bali bukan hanya sekedar hiburan tetapi memiliki arti sakral. Pada prinsipnya tarian di Bali mengikuti prinsip berdasarkan desa (tempat), kala (waktu), dan patra (acara) dan melambangkan tradisi tertentu, kebiasaan dan nilai-nilai agama berkaitan dengan jiwa (spirit). Dengan disertai dengan musik gamelan dengan gerakan yang dinamis dan berbagai ekspresi wajah, gerakan mata mengungkapkan kebahagiaan, kesedihan, kemarahan, ketakutan, dan cinta berkaitan dengan pikiran (mine) dan tubuh (body). Para penari selain harus tampil secara teknis juga harus memiliki kerendahan hati, disiplin, kharisma yaitu energi spiritual khusus yang menghidupkan tarian. Dalam Masyarakat bali tarian ditransmisikan secara informal kepada anak-anak sejak usia dini dalam belajar (kelompok adat). Pelatihan dimulai dengan gerakan tari dasar dan posisi, kemudian berkembang menjadi tarian yang lebih rumit, sesi berlajut sampai siswa telah hafal urutan gerakan. Tari tradisional Bali memberikan rasa identitas yang kuat didasarkan pada pemahaman bahwa mereka menjaga warisan budaya nenek moyang mereka.

Dalam hubungan ini, tawaran pendidikan melalui seni menjadi suatu keniscayaan. Sebagai contoh bentuk pembelajaran seni tari yang mempelajari beragam tarian di Indonesia yang diajarkan dalam kurikulum pendidikan formal maupun nonformal maupun dalam institusi tertentu sebagai mata pelajaran Tari Nusantara seperti Tari Bedhaya Ketawang dari Daerah Jawa Tengah, Tari Saman dari Aceh, Tari Kecak dari Bali, Tari Piring dari Minangkabau Sumatra Barat, Tari Serimpi Yogyakarta, Tari Kipas Pakarena dari Daerah Sulawesi Selatan. Di dalam pendidikan apresiasi seni ini, peserta didik dihadapkan langsung pada multikulturalisme, dan dapat mengekspresikan diri dari beragam budaya yang ada. Dalam artian bahwa subjek didik bukan hanya terampil dalam penyajiannya akan tetapi dapat mengetahui isi, simbol, sejarah, dan estetika dalam bentuk fisik materi seninya. Artinya, subjek didik diajari untuk menghormati budaya lain. Sehingga tujuan yang hendak dicapai 
adalah peserta didik mengalami situasi sadar dan cerdas budaya sekaligus menjadi sadar adanya pluralisme bangsa.

Kebebasan individu, sejalan dengan prinsip dalam seni yakni suatu hal yang bersifat kreatif. Oleh Zimmerman dalam A Journal of Issues and Research. (50(4), 2009:382-399) Kreativitas dari sudut pandang ini adalah seorang individu dengan karakteristik sebagai seseorang yang bereaksi dengan satu atau lebih sistem dalam konteks sosial tertentu. Dalam era masyarakat industrial dan informasi, kreativitas merupakan bidang multidimensi tempat seniman, penghibur, dan produsen budaya terlibat. Freedman (dalam Zimmerman, 2009) mengemukakan bahwa di masa lalu produksi artistik siswa ditandai sebagai bentuk ekspresi diri. Dalam konteks kontemporer, produksi kreatif dianggap bukan hanya sekadar ekspresi diri namun sebagai pengembangan identitas budaya dan pribadi. Freedman menyerukan pentingnya rekonseptualisasi kreativitas sebagai tindakan kepemimpinan dan sebagai pementukan ekspresif artistik.

Mengutip Bramantyo (2012; 13-15) tentang masalah dalam pengembangan pendidikan musik di Indonesia dapat menjadi rujukan dalam mengembagkan apresiatif estetis peserta didik. Salah satu permasalahan yang kemudian di jelaskan adalah tidak diperkenalkannya idiom-idiom musikal masyarakat indonesia dalam pengajaran kesenian di Indonesia. Sebagai contoh dalam menjelaskan uraian tersebut, akan dikemukakan beberapa karya musik berikut ini;

(1) "Wah", karya Gatot Santoso (1981), diilhami idiom-idiom tradisional yang hidup dan dipertahankan secara selaras oleh masyarakat petani di Delanggu, yakni "pande besi" dengan teknologi sederhana. Idiom-idiom itu muncul dalam keseluruhan aspek-aspek kehidupan mereka, termasuk cara mereka "memande besi" secara ritmis (kemudian disebut musikal) (2) "Ati Raja", karya orkestrasi oleh Nikolai. Diilhami oleh lagu rakyat Sulawesi Selatan dalam judul yang sama dengan ungkapan-ungkapan idiom melodi dan irama perkusi yang asli (3) "Di Bawa Sinar Bulan Purnama", aransemen Jose Cleber, diilhami lagu keroncong ciptaan Maladi dalam judul yang sama. Teknik harmonisasi yang sangat barat, ternyata dapat mengangkat lagu rakyat dalam suasana orkes yang serius (4) "Tabuh-Tabuhan", karya orkestrasi Collin Mc. Phee. Diilhami oleh musik tradisional Bali, diangkat dalam orkes simfoni dengan beberapa perubahan teknis untuk mencapai nuansa asli musik Bali. Ekspresi memainkannya kontrabas dengan cerdik mengulur tempo menirukan suara gong. (ibid. Hal. 14).

Dari empat contoh diatas, dapat mewakili dari berbagai macam kesenian sebagai warisan budaya sebagai hasil gagasan yang sifatnya ekspresif artistik. Contoh ini dapat dikembangkan sebagai sebuah referensi yang memiliki nilai estetis universal. Tentu masih banyak contoh lain, Sebut saja Gamelan hasil gubahan C.A Debussy. Menurutnya, Gamelan Jawa ketika didengarkan memiliki nilai estetis dan filosifis yang tinggi sehingga mengantarkannya dalam berekspresi artistik yang dapat di liat pada karyanya "Prelude d'apes Midi d'un Faune". Debussy mengenalkan konsep harmoni yang disebut dengan dissonant yang banyak digunakan dalam karawitan Jawa.

Dari contoh tersebut peranan kesenian sangat kuat dalam membentuk suatu kreativitas namun tidak merubah nilai-nilai budaya yang telah ada, di sisi lain, juga sebagai mempertahankan atau mewariskan, dan sebagai media pembelajaran lintas budaya, dan mengutip dari Sumaryanto (2016) adalah sebagai suatu komunikasi budaya. Adapun fenomena yang terjadi yang dapat dijadikan sebagai rujukan apresiasi estetis maupun dalam berekspresif artistik terdapat dalam dalam fenomena "Batik". Hasil dari kreativitas budaya ini 
merupakan sebuah warisan yang patut disyukuri. Kesenian batik yang telah di akui sebagai warisan budaya (culture heritage) dari badan dunia UNESCO pada tahun 2009 (dalam Sutiyono, 2012;30). Dengan pengakuan tersebut, batik kemudian muncul sebagai fenomena sosial baru, hal ini, ditandai dengan mewajibkan para guru dan para siswa untuk mengenakan pakaian batik. Fenomena ini kemudian tersebar ke berbagai-berbagai daerah di Indonesia, sebut saja di Kota Makassar dan Kabupaten-Kabupaten kota di daerah Sulawesi Selatan yang notabene bukan merupakan daerah seni batik berasal. Pada umumnya guru, para siswa, maupun pegawai pemerintahan di Provinsi Sulawesi Selatan secara umum telah membudayakan mengenakan pakaian batik pada hari tertentu. Bukan hanya digunakan sebagai seragam sekolah tetapi pendidikan dan pelatihan krativitas membatik juga telah diajarkan kepada kolompok masyarakat dalam pendidikan nonformal maupun kepada subjek didik pada pendidikan formal tertentu. Sadar ataupun tidak fenomena ini merupakan sebuah proses pendidikan sebagai media apresiatif estetis dan ekspresif artistik bagi lapisan masyarakat yang menghargai warisan budaya di luar dari hasil budaya mereka.

Menurut Bandem (Sutiyono 2012:70) di sini peran pendidikan seni yang mengekspresikan berbagai kesenian dapat dijadikan sebagai ramuan penawar terhadap persoalan bangsa yang akhir-akhir ini sebagaimana dapat dicermati bersama. Oleh karena pendidikan seni yang berwawasan multibudaya menawarkan jembatan sejajar bagi kelompok yang berbeda budaya untuk hidup bersama. Lewat jalur pendidikan seni maka dapat dibangun kembali kesadaran multikultural secara nasional melalui pelestarian, penguatan, dan pengembangan.

\section{Penutup}

Landasan paradigma pendidikan seni dari sudut pandang kebudayaan menegaskan landasan pendidikan sebagai pembentukan jati diri, yang cerdas, berkarakter, inovatif, kreatif, dan memiliki daya apresiatif yang tinggi tepat jika pendidikan berbasis kesenian dijadikan sebagai sebuah pendekatan atau sebagai media dalam satuan pendidikan. Tradisi liberal dalam sistem pendidikan akan memberikan ruang pada individu untuk mengembangkan kepercayaan diri, Paham liberal melaui spirit humanisme dalam pendidikan seni tak lepas dari menuntun manusia menjadi sesosok yang percaya diri, menghargai pendapat orang lain, dan bertanggung jawab melalui berkegiatan seni dalam upaya mengembangkan kreativitas dan ekspresinya sehingga terbentuk pribadi yang kreatif dan memiliki kesadaran dalam menghargai nilai-nilai budaya sebagai anggota masyarakat.

Dalam sudut pandang paradigma pendidikan seni melalui ideologi liberal dan ideologi konservatif. Melalui ideologi liberal akan memberikan ruang pada individu untuk mengembangkan kepercayaan diri, serta tujuan pendidikan adalah hak individu dengan kekebasannya. Melalui pendekatan pendidikan dalam seni dalam konsep education in art, sejalan dengan paham liberal dengan mementingkan kepada rana ekspresif estetik atau kreativitas individu sebagai tujuan pendidikan dalam seni dengan memberikan kepada subjek didik motivasi dalam menumbuhkan kreativitas. Sehingga mampu mengatasi segala masalah yang berkembang di lingkungannya. Adapun ideologi konservatif melalui pendidikan seni memusatkan perhatiannya pada perlunya melestarikan dan meneruskan keyakinan dan praktik seni yang sudah mapan, sebagai cara untuk menjamin pertahanan hidup secara sosial. Peran dan fungsi inilah yang menjadi wujud dalam kegiatan aprasitif estetis.

Pengaplikasian pendidikan musik berlatar belakang dari dimensi pendekatan holistik dalam paraktek pengajaran seni yang digolongkan dalam pikiran, tubuh, dan jiwa. Peran 
pendidikan musik di sini memiliki substansi mengekspresikan berbagai hasil kreativitas budaya sehingga dapat dijadikan sebagai alat atau media dalam menghadapi berbagai persoalan bangsa. Oleh karena pendidikan seni yang berwawasan multibudaya menawarkan jembatan sejajar bagi kelompok yang berbeda budaya untuk hidup bersama. Lewat jalur pendidikan seni maka dapat dibangun kembali kesadaran multikultural secara nasional melalui pelestarian, penguatan, dan pengembangan. Metode pembelajaran melalui pendidikan musik dirincikan bahwa pendidik harus berfungsi sebagai agen pembaharuan berperan sebagai komunikator, berfungsi sebagai pelayanan yang dilandasi olah rasa, profesional yang selalu sadar akan tanggung jawab, dan berfungsi sebagai narasumber yang terpercaya.

Pendidikan seni sebagai penguatan karakter memiliki posisi dan peran yang sangat strategis dalam membantu merekonstruksi kepribadian individu ke arah yang lebih kreatif, inovatif, bertanggung jawab, disiplin, mandiri, jujur, terbuka, tekun, dan apresiatif. Melalui Paradigma pendidikan seni dengan menjadikan seni sebagai media dalam pembelajaran potensi pembentukan nilai karakter secara langsung akan terbangun sejak dini. Dengan demikian, pendidikan seni layak diarahkan untuk memposisikan diri dalam melakukan kajian yang sifatnya rasional dalam mengembangkan pengetahuan ilmiah menuju arah dan tujuan pendidikan nasional secara berkala.

\section{References}

Anwar, Muhammad. 2015. Filsafat Pendidikan. Jakarta: Prenadamedia Group.

Bramantyo, Triyono. 2012. Musik: Pendidikan Budaya Tradisi. Yogyakarta: Badan Penerbit ISI Yogyakarta.

Jalaluddin, H., \& Idi,H.A. 2011. Filsafat pendidikan: manusia, filsafat, dan pendidikan. Jakarta: Divisi Buku Perguruan Tinggi, PT Rajagrafindo Persada

Janíková, M., \& Kowaliková, P. (2017). Technical Education in the Context of the Fourth Industrial Revolution. Journal for Research and Education, Spesial Issue (December), 65-73.

Kementrian Pendidikan dan Kebudayaan. 2016. Majalah Jendela Ayo Daftarkan Dirimu edisi IV Agustus. Jakarta : BKLM Kemendikbud

Kementrian Pendidikan dan Kebudayaan. 2016. Majalah Jendela Penguatan Pendidikan Karakter ; Menyikapi Siswa Dengan Karakter Mulia dan Kompetensi di Abad Ke-21 edisi VII Desember. Jakarta : BKLM Kemendikbud

O’Neill, F. William. 1981. Educationnal Ideologies : Contemporary of Educational Philosophies (terjemahan Mansour Fakih). Yogyakarta : Pusaka Pelajar.

Pamadhi, Hajar. 2012. Pendidikan Seni : Hakikat Kurikulum Pendidikan Seni, Habitus Seni, dan Pengajaran Seni Anak. Yogyakarta : UNY Press.

Puncreobutr, V. (2016). Education 4.0: New Challenge of Learning. St.Therasa Journal of Humanities and Social Sociences, 2(2), 92-97

Rohidi, Tjetjep Rohendi. 2014. Pendidikan Seni Isu dan Paradigma. Semarang : Cipta Prima Nusantara.

Soehardjo, A.J. 2012. Pendidikan Seni : Dari Konsep Sampai Program. Malang : Bayumedia Publishing, Universitas Negeri Malang. 
Soyomukti, Nuraini. 2015. Teori-Teori Pendidikan : Dari Tradisional (Neo) Liberal Marxis Sosialis Hingga Postmodern. Yogyakarta : Ar Ruzz Media.

Sumaryanto, Totok. 2016. "Membumikan Seni Pertunjukan Tradisional Melalui Revolusi Mental Menuju Pembangunan Yang Berkepribadian Budaya". Makalah Seminar Nasional. Universitas Negeri Semarang 22 Oktober.

Sutiyono. 2012. Paradigma Pendidikan Seni di Indonesia. Yogyakarta : UNY Press.

Sumardianta, J., \& AW, W. K. (2018). Mendidik Generasi Z \& A. Jakarta: Grasindo.

Tilaar, H.A.R. 2012. Kaleidoskop Pendidikan Indonesia. Jakarta: PT Kompas Media Nusantara.

Triyanto. 2017. Spirit Ideologi Pendidikan Seni. Semarang : Cipta Prima Nusantara.

Yakin, M. Ainul. 2005. Pendidikan Multikultural : Cross-Cultural Understanding Untuk Demokrasi dan Keadilan. Yogyakarta : Pilar Media. 